\title{
The effects of 30 days resveratrol supplementation on adipose tissue morphology and gene expression patterns in obese men.
}

\author{
Citation for published version (APA):
}

Konings, E., Timmers, S., Boekschoten, M. V., Goossens, G. H., Jocken, J. W., Afman, L. A., Muller, M., Schrauwen, P., Mariman, E. C., \& Blaak, E. E. (2014). The effects of 30 days resveratrol supplementation on adipose tissue morphology and gene expression patterns in obese men. International Journal of Obesity, 38(3), 470-473. https://doi.org/10.1038/ijo.2013.155

Document status and date:

Published: 01/03/2014

DOI:

10.1038/ijo.2013.155

Document Version:

Publisher's PDF, also known as Version of record

\section{Document license:}

Taverne

Please check the document version of this publication:

- A submitted manuscript is the version of the article upon submission and before peer-review. There can be important differences between the submitted version and the official published version of record.

People interested in the research are advised to contact the author for the final version of the publication, or visit the DOI to the publisher's website.

- The final author version and the galley proof are versions of the publication after peer review.

- The final published version features the final layout of the paper including the volume, issue and page numbers.

Link to publication

\footnotetext{
General rights rights.

- You may freely distribute the URL identifying the publication in the public portal. please follow below link for the End User Agreement:

www.umlib.nl/taverne-license

Take down policy

If you believe that this document breaches copyright please contact us at:

repository@maastrichtuniversity.nl

providing details and we will investigate your claim.
}

Copyright and moral rights for the publications made accessible in the public portal are retained by the authors and/or other copyright owners and it is a condition of accessing publications that users recognise and abide by the legal requirements associated with these

- Users may download and print one copy of any publication from the public portal for the purpose of private study or research.

- You may not further distribute the material or use it for any profit-making activity or commercial gain

If the publication is distributed under the terms of Article $25 \mathrm{fa}$ of the Dutch Copyright Act, indicated by the "Taverne" license above, 


\title{
SHORT COMMUNICATION
}

\section{The effects of 30 days resveratrol supplementation on adipose tissue morphology and gene expression patterns in obese men}

\author{
E Konings ${ }^{1,5}$, S Timmers ${ }^{1,2,5}$, MV Boekschoten ${ }^{3,4}$, GH Goossens ${ }^{1}$, JW Jocken ${ }^{1}$, LA Afman ${ }^{3,4}$, M Müller ${ }^{3,4}$, P Schrauwen ${ }^{1,2}$, EC Mariman ${ }^{1}$ and \\ EE Blaak ${ }^{1}$
}

Polyphenolic compounds, such as resveratrol, have recently received widespread interest because of their ability to mimic effects of calorie restriction. The objective of the present study was to gain more insight into the effects of 30 days resveratrol supplementation on adipose tissue morphology and underlying processes. Eleven healthy obese men were supplemented with placebo and resveratrol for 30 days $(150 \mathrm{mg}$ per day), separated by a 4-week washout period in a double-blind randomized crossover design. A postprandial abdominal subcutaneous adipose tissue biopsy was collected to assess adipose tissue morphology and gene expression using microarray analysis. Resveratrol significantly decreased adipocyte size, with a shift toward a reduction in the proportion of large and very-large adipocytes and an increase in small adipocytes. Microarray analysis revealed downregulation of Wnt and Notch signaling pathways and upregulation of pathways involved in cell cycle regulation after resveratrol supplementation, suggesting enhanced adipogenesis. Furthermore, lysosomal/phagosomal pathway and transcription factor EB were upregulated reflecting an alternative pathway of lipid breakdown by autophagy. Further research is necessary to investigate whether resveratrol improves adipose tissue function.

International Journal of Obesity (2014) 38, 470-473; doi:10.1038/ijo.2013.155

Keywords: resveratrol; adipose tissue; microarray

\section{INTRODUCTION}

Obesity is reaching epidemic proportions and is associated with insulin resistance and an increased risk for type 2 diabetes mellitus. ${ }^{1}$ Polyphenolic compounds, such as resveratrol, are currently an area of intense investigation because of their ability to mimic effects of calorie restriction. Pronounced effects of resveratrol have been reported on lipolysis, adipogenesis and inflammation in isolated adipocytes and on adipose tissue of murine animals. ${ }^{2}$ These effects may possibly reflect changes in adipose tissue function and an improved insulin sensitivity. ${ }^{3}$ On the other hand, a mice study with resveratrol showed an inhibition of adipogenesis. ${ }^{4}$ Although the latter finding has been implicated in the prevention of body fat accumulation in this study, this may also reflect impaired adipogenic potential resulting in a reduced adipose tissue expandability and insulin resistance. ${ }^{5}$

A recent human study observed no changes in adipose tissue mass (total, subcutaneous or visceral fat), adipose tissue or muscle metabolic and inflammatory gene expression profiles and insulin sensitivity after 4 weeks of a high daily dose of resveratrol (1500 mg per day) in obese healthy men. ${ }^{6}$ In another study of Yoshino et al. in non-obese postmenopausal women, resveratrol supplementation (75 mg per day) did not affect liver, muscle or adipose tissue insulin sensitivity or its putative molecular targets in adipose tissue or muscle. ${ }^{7}$ In contrast, in a recent study in our laboratory, it was shown that resveratrol supplementation for 4 weeks (150 mg per day) induced metabolic changes in liver and skeletal muscle metabolism in obese humans, mimicking the effects of calorie restriction. ${ }^{8}$ These data may suggest that the resveratrol-induced metabolic effects may depend on the administered dose or to what extent the metabolic state is compromised.

The general aim of the present work was to gain more insight into the effects of 30 days resveratrol supplementation $(150 \mathrm{mg}$ per day) on adipose tissue morphology and the transcriptional profile using microarray analysis in healthy obese men.

\section{PATIENTS AND METHODS}

Study design

The current study was part of a previously published randomized doubleblind crossover study. ${ }^{8}$ Eleven obese, healthy men participated in two trials for 30 days: a placebo and resVida $(150 \mathrm{mg}$ per day trans-resveratrol (99.9\%; DSM Nutritional Products, Kaiseraugst, Switzerland)) condition with a 4-week washout period. At the end of both intervention periods, a subcutaneous adipose tissue biopsy was taken $6 \mathrm{~h}$ after ingestion of a high-fat liquid test meal. ${ }^{8}$ The original study protocol was approved by the Medical Ethical Committee of Maastricht University Medical Center and written informed consent was obtained before study participation.

\section{Abdominal subcutaneous adipocyte size}

Processing and analysis of subcutaneous adipose tissue biopsies for adipocyte size have been described in detail previously. ${ }^{9}$ Briefly, an adipose tissue needle biopsy $(\sim 1 \mathrm{~g})$ was collected $6-8 \mathrm{~cm}$ lateral from the umbilicus. Part of the adipose tissue was fixed overnight in $4 \%$ paraformaldehyde and embedded in paraffin for histological sections

${ }^{1}$ Department of Human Biology, NUTRIM School for Nutrition, Toxicology and Metabolism, Maastricht University Medical Center,+ Maastricht, The Netherlands; ${ }^{2}$ Top Institute Food and Nutrition (TIFN), Wageningen, The Netherlands; ${ }^{3}$ Nutrition, Metabolism and Genomics group, Division of Human Nutrition, Wageningen University, Wageningen, The Netherlands and ${ }^{4}$ Netherlands Nutrigenomics Centre, TI Food and Nutrition, Wageningen, The Netherlands. Correspondence: Professor EE Blaak, Department of Human Biology, NUTRIM School for Nutrition, Toxicology and Metabolism, Maastricht University Medical Center + , PO Box 616, Maastricht 6200 MD, The Netherlands.

E-mail: e.blaak@maastrichtuniversity.nl

${ }^{5}$ These authors contributed equally to this work.

Received 9 March 2013; revised 7 July 2013; accepted 8 August 2013; accepted article preview online 20 August 2013; advance online publication, 10 September 2013 
$(8 \mu \mathrm{m})$, whereas the other part was snap frozen in liquid nitrogen and stored at $-80^{\circ} \mathrm{C}$. Sections were stained with hematoxylin and eosin. Digital images were captured and computerized morphometric analysis of individual adipocytes was performed in a blinded manner.

\section{Adipose tissue gene expression}

Microarray processing. Total RNA was extracted from frozen adipose tissue specimens using TRIzol reagent (Invitrogen, Breda, The Netherlands) and purified on columns using the Qiagen RNeasy Micro Kit (Qiagen, Venlo, The Netherlands). Total RNA (100 ng per sample) was labeled by Whole-Transcript Sense Target Assay and hybridized to human whole-genome Affymetrix Gene 1.1 ST arrays targeting 19793 unique genes (Affymetrix, Santa Clara, CA, USA).

Microarray data analysis. Quality control and data analysis have been described in detail previously. ${ }^{8}$ Individual genes were defined as changed when comparison of the normalized signal intensities showed a $P$-value $<0.05$ in a two-tailed paired intensity-based moderated t-statistics (PMID:17177995). These analyses were performed within MADMAX system (PMID:21778530). Further functional data analysis was performed on the filtered data set ( $>5$ arrays with signal intensity $>20$ ) with Gene Set Enrichment Analysis (http://www.broad.mit.edu/gsea/) and gene sets were selected based upon a FDR $q$-value $<0.25$. A transcription factor analysis was performed on the differentially expressed genes ( $P$-value $<0.05$ ) with Ingenuity Pathway Analysis (June 2012, Ingenuity Systems, Redwood City, CA, USA). Array data have been submitted to the Gene Expression Omnibus GSE42432.

\section{Statistics}

Student's paired $t$-test was used to compare placebo and resveratrol supplementation in normally distributed data. A $P$-value $<0.05$ was considered statistically significant. Data are reported as mean \pm s.e.m. Statistical analyses were performed using the statistical program SPSS 16.0 (SPSS Inc., Chicago, IL, USA).

\section{RESULTS}

Subject characteristics

Eleven obese male volunteers aged 40-65 years and body mass index between 28 and $36 \mathrm{~kg} \mathrm{~m}^{-2}$ participated in this study. Other
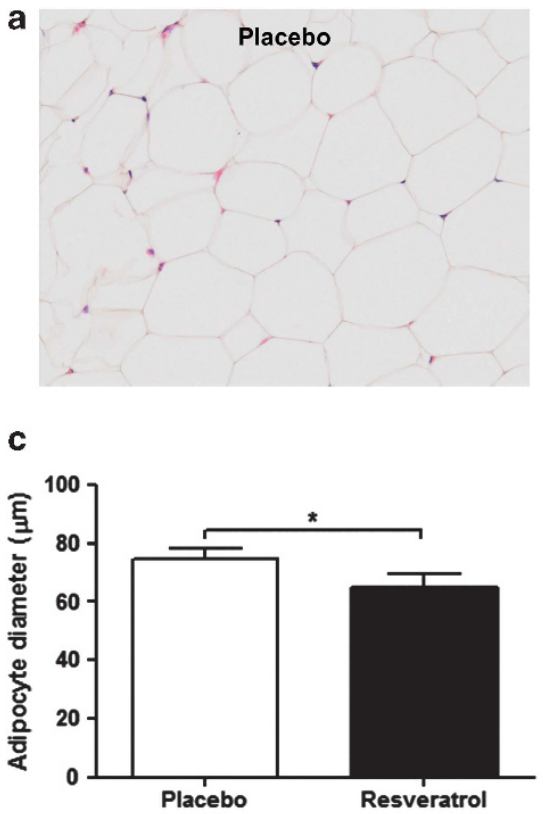

subject characteristics and effects of 30 days resveratrol on plasma biochemistry have previously been reported. ${ }^{8}$

Resveratrol decreased abdominal subcutaneous adipocyte size Mean adipocyte size was decreased after 30 days resveratrol $(65.0 \pm 4.4 \mu \mathrm{m})$ compared with placebo $(74.7 \pm 3.5 \mu \mathrm{m}$; Figure $1 \mathrm{c})$. This was attributed by a shift toward a lower proportion of very large adipocytes $(>90 \mu \mathrm{m})$ and an increased proportion of small adipocytes $(<50 \mu \mathrm{m})$. The proportion of large $(70-89 \mu \mathrm{m})$ adipocytes also tended to be lower after resveratrol supplementation (Figure 1d). A representative image is shown in Figures $1 \mathrm{a}$ and $\mathrm{b}$.

\section{Microarray analysis}

From the 19793 genes on the array, 12676 genes were expressed in adipose tissue. Resveratrol supplementation resulted in changed expression of 582 genes, of which 290 were upregulated and 292 were downregulated.

Gene set enrichment analysis

Gene sets that were downregulated by resveratrol belonged to pathways involved in cell-cell junction, Wnt signaling, angiogenesis, G protein coupled receptors and Notch signaling (Figure 2a). Gene sets upregulated by resveratrol were associated with lysosome, phagosome, inflammation, glucose/hexose transport and cell cycle (Figure 2b). Upregulated pathways associated with inflammation included interferon signaling, antigen processing and presentation, T-cell receptor signaling and nuclear factor $\kappa B$ activation (Supplementary Table 1). Core-enriched genes per up- and downregulated pathways are presented in Supplementary Table 2.

\section{Transcription factor analysis}

Several transcription factors involved in interferon signaling were identified as potentially activated (Supplementary Table 3). Furthermore, the nuclear factor $\kappa B$ complex involved in inflammation, PPAR $\delta$ and transcription factor EB (TFEB), which links autophagy to lysosomal biogenesis, were shown to be activated. ${ }^{10}$
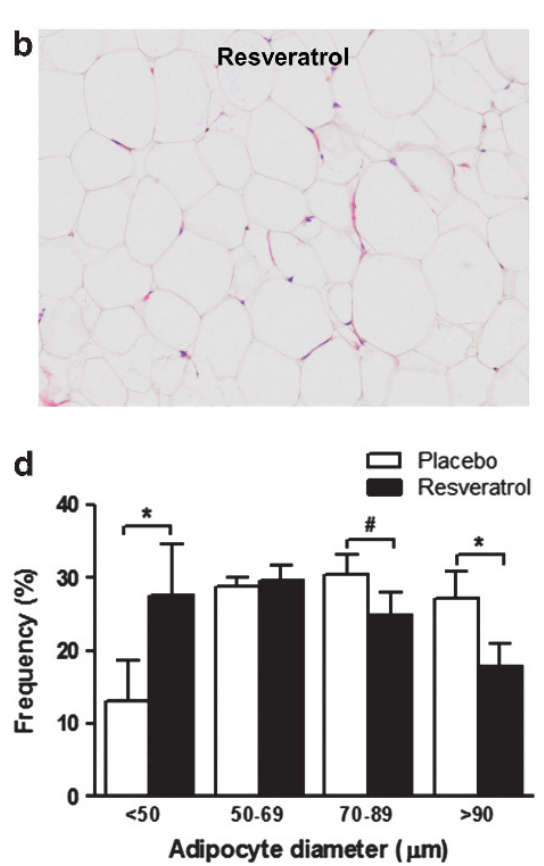

Figure 1. Adipocyte size measurement after placebo and resveratrol supplementation. Representative adipose tissue sections after placebo (a) and resveratrol (b) supplementation ( $\times 20$ magnification). (c) Mean adipocyte diameter. (d) Adipocyte size distribution. $N=8$. Values are means \pm s.e.m. ${ }^{\#} P<0.1,{ }^{*} P<0.05$. 


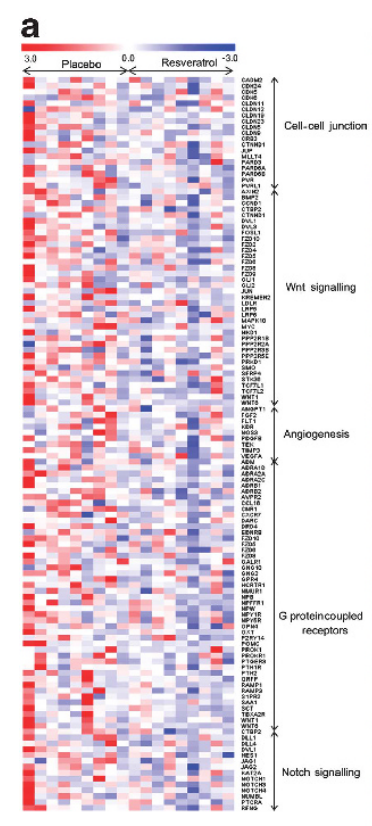

b
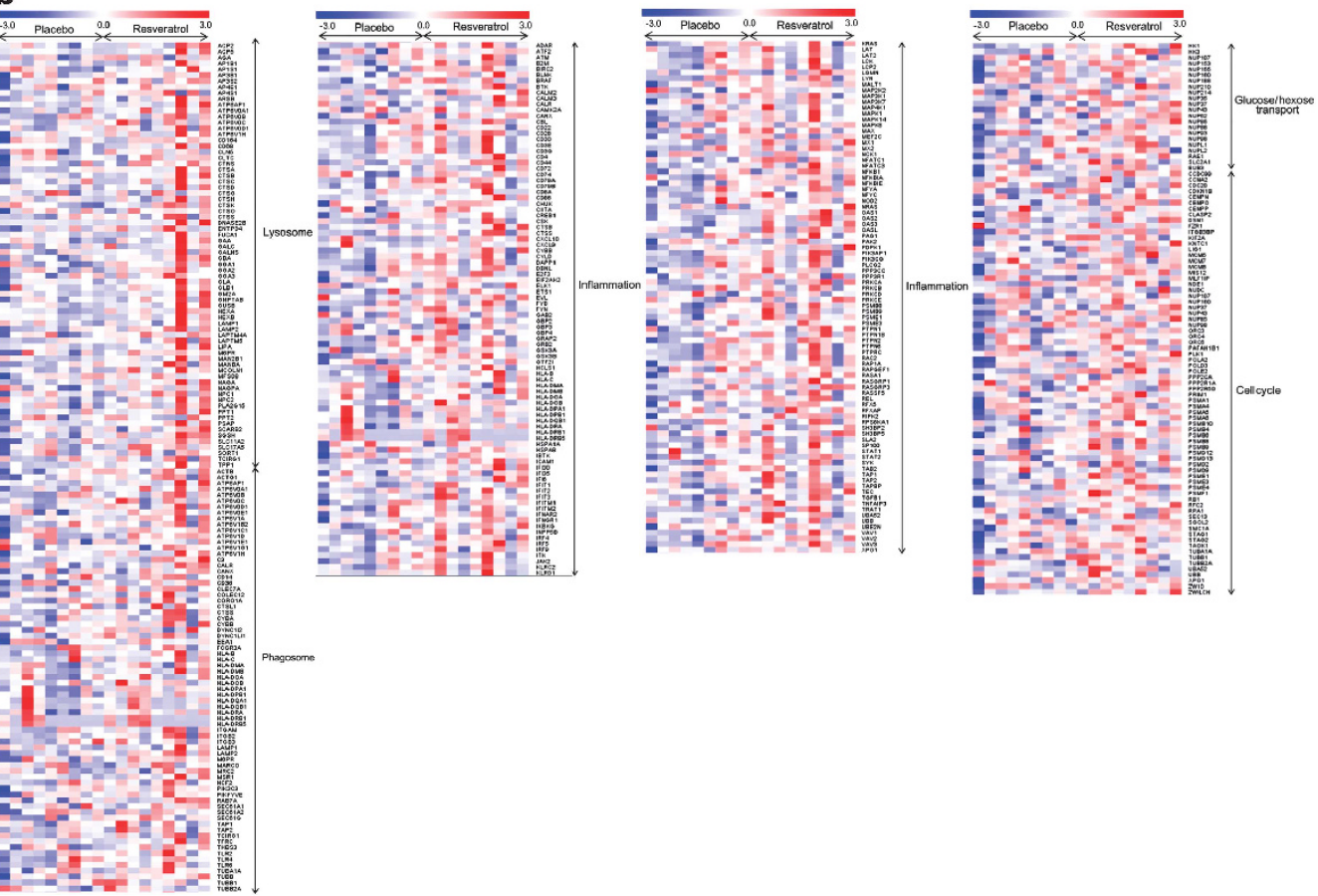

Figure 2. Up- and downregulated gene sets after resveratrol supplementation using gene set enrichment analysis. (a) Downregulated gene sets after resveratrol supplementation. (b) Upregulated gene sets after resveratrol supplementation. The $z$-score was calculated by subtracting the mean expression value for each transcript from each of the values and then dividing the resulting values by the standard deviation. Only the core-enriched genes are represented in this figure. Color in the heat-maps reflects the relative transcript abundance level with red being higher and blue lower than the mean transcript abundance value.

Transcription factors that were identified as inhibited included Notch 4 and SMAD4 (Supplementary Table 3). The transcription factor hypoxia-inducible factor $1-\alpha$ was also inhibited.

\section{DISCUSSION}

Resveratrol significantly decreased adipocyte size, with a shift toward a lower proportion of large and very large adipocytes and an increased proportion of small adipocytes. Gene expression analysis indicated an increased adipogenesis and an altered pathway of lipid breakdown by autophagy. Together, these data suggest that the reduced mean adipocyte size may underlie the previously reported improved insulin sensitivity in these subjects, as a reduced adipocyte size in combination with an improved adipogenesis may be related to an improved insulin sensitivity in humans. ${ }^{11}$

Microarray analysis indicated that the Wnt signaling and Notch signaling pathway were downregulated after resveratrol supplementation. Inhibition of these pathways has shown to result in adipogenesis of preadipocytes and/or multipotent precursor cells, ${ }^{12,13}$ although the exact role in adipogenesis needs to be further elucidated. Gene sets associated with cell cycle were upregulated by resveratrol. This indicates that an increased adipogenesis could possibly explain the reduced adipocyte size after resveratrol. In contrast to our in vivo observations, in vitro experiments performed in murine and human adipocyte cell lines have shown that resveratrol inhibited proliferation and adipogenic differentiation. ${ }^{14,15}$ The discrepancy between in vitro results and the present data may be explained by differences in resveratrol concentrations, acute in vitro vs chronic in vivo administration and the presence of stromal vascular cell types (for example, inflammatory cells) in the in vivo situation.
Our data show that the angiogenesis pathway was downregulated in human adipose tissue after resveratrol supplementation. Furthermore, the transcription factor hypoxia-inducible factor $1-\alpha$ whose activity is induced by hypoxia, insulin and nitric oxide ${ }^{16}$ was also downregulated. These data are consistent with studies showing that resveratrol possesses anti-angiogenic effects, ${ }^{17}$ but further research is necessary to determine the exact role of resveratrol on angiogenesis in adipose tissue.

Interestingly, activation of a lysosomal pathway of lipid breakdown was demonstrated. Until recently, mobilization of lipids by the classic lipolytic pathway has only been attributed to lipid droplet-associated proteins and lipases. Lately, an alternative pathway of lipid metabolism has been proposed through the lysosomal degradative pathway of autophagy. Major support for the involvement of autophagy is the activation of TFEB following resveratrol supplementation in the present study. TFEB controls multiple crucial steps of the autophagic pathway. ${ }^{10}$ Studies in hepatocytes and liver have demonstrated lipid breakdown by autophagy. ${ }^{18}$ In preadipocytes, inhibition of autophagy has shown to block adipogenesis. ${ }^{19}$ Therefore, in the present study, the lysosome and phagosome pathways, may have contributed both to an induction of adipogenesis as well as to alternative lipid breakdown, possibly contributing to the shift toward an increased proportion of small adipocytes after resveratrol.

In the present study, several pathways involved in the immune response were upregulated after resveratrol treatment. This may reflect an increase in cellular stress induced by the reduction in adipocyte size caused by traction forces between the adipocyte and the surrounding extracellular matrix. This may induce upregulation of inflammatory genes and pro-inflammatory adipokine production, as shown after weight loss. ${ }^{20}$ On the other hand, upregulation of immune response pathways may be a physiological response to a higher lipid turnover (that is, 
lysosomal lipid breakdown). We previously observed in these subjects a decrease in plasma interleukin- 6 and tumor necrosis factor- $\alpha$ concentrations and a downregulation of gene sets associated with immune response in skeletal muscle following resveratrol supplementation. ${ }^{8}$ These findings indicate that the increased immune response in adipose tissue could represent a local rather than a systemic response. ${ }^{8}$

The present results show that resveratrol increased pathways in the adipose tissue involved in glucose and hexose transport as evidenced by GSEA. However, in vitro data concerning the effects of resveratrol on glucose transport are conflicting. ${ }^{15}$ It needs to be further established if the observed increase in glucose/hexose transport pathway, translates into a functional increase in glucose uptake.

As indicated above, resveratrol clearly affected adipose tissue gene expression profiles. This is in contrast with two recent human trials, which did not show any effects on adipose tissue metabolism or gene expression after resveratrol supplementation. ${ }^{6,7}$ The reason for this discrepancy may possibly lie in the administered dose, which was very high in the study of Poulsen et al. (1500 mg per day) as compared with our study or the healthier metabolic status of the subjects in the study of Yoshino et al. ${ }^{6,7}$

In conclusion, resveratrol supplementation for 30 days induced a shift toward an increased proportion of small adipocytes. This phenotype was accompanied by a gene expression profile indicative of increased adipogenesis, an alternative pathway of lipid breakdown by autophagy and an increased immune and inflammatory response. Further research is necessary to investigate whether resveratrol improves adipose tissue function.

\section{CONFLICT OF INTEREST}

The authors declare no conflict of interest.

\section{ACKNOWLEDGEMENTS}

We thank Jos Stegen and Yvonne Essers for their excellent technical assistance with the biochemical analysis and adipocyte cell size analysis. This study was funded by Top Institute Food and Nutrition. TI Food and Nutrition, formerly known as WCFS, is a unique public/private partnership that generates vision on scientific breakthroughs in food and nutrition, resulting in the development of innovative products and technologies that respond to consumer demands for safe, tasty and healthy foods. Partners are major Dutch food companies and research organizations. We also thank DSM Nutritional Products Ltd., Kaiseraugst, Switzerland for providing us with the resVida ${ }^{\mathrm{TM}}$ and placebo capsules.

\section{REFERENCES}

1 Harris MI, Flegal KM, Cowie CC, Eberhardt MS, Goldstein DE, Little RR et al. Prevalence of diabetes, impaired fasting glucose, and impaired glucose tolerance in U.S. adults. The Third National Health and Nutrition Examination Survey, 1988-1994. Diabetes Care 1998; 21: 518-524.

2 Szkudelska K, Szkudelski T. Resveratrol, obesity and diabetes. Eur J Pharmacol 2010; 635: 1-8.
3 Baur JA, Pearson KJ, Price NL, Jamieson HA, Lerin C, Kalra A et al. Resveratrol improves health and survival of mice on a high-calorie diet. Nature 2006; 444: 337-342.

4 Kim S, Jin Y, Choi Y, Park T. Resveratrol exerts anti-obesity effects via mechanisms involving down-regulation of adipogenic and inflammatory processes in mice. Biochem Pharmacol 2011; 81: 1343-1351.

5 McLaughlin T, Sherman A, Tsao P, Gonzalez O, Yee G, Lamendola C et al. Enhanced proportion of small adipose cells in insulin-resistant vs insulinsensitive obese individuals implicates impaired adipogenesis. Diabetologia 2007; 50: 1707-1715.

6 Poulsen MM, Vestergaard PF, Clasen BF, Radko Y, Christensen LP, Stodkilde-Jorgensen $\mathrm{H}$ et al. High-dose resveratrol supplementation in obese men: an investigator-initiated, randomized, placebo-controlled clinical trial of substrate metabolism, insulin sensitivity, and body composition. Diabetes 2013; 62: 1186-1195.

7 Yoshino J, Conte C, Fontana L, Mittendorfer B, Imai S, Schechtman KB et al. Resveratrol supplementation does not improve metabolic function in nonobese women with normal glucose tolerance. Cell Metab 2012; 16: 658-664.

8 Timmers $\mathrm{S}$, Konings $\mathrm{E}$, Bilet $\mathrm{L}$, Houtkooper RH. van de Weijer T, Goossens GH et al. Calorie restriction-like effects of 30 days of resveratrol supplementation on energy metabolism and metabolic profile in obese humans. Cell Metab 2011; 14: 612-622.

9 Goossens GH, Bizzarri A, Venteclef N, Essers Y, Cleutjens JP, Konings E et al. Increased adipose tissue oxygen tension in obese compared with lean men is accompanied by insulin resistance, impaired adipose tissue capillarization, and inflammation. Circulation 2011; 124: 67-76.

10 Settembre C, Di Malta C, Polito VA, Garcia Arencibia M, Vetrini F, Erdin S et al. TFEB links autophagy to lysosomal biogenesis. Science 2011; 332: 1429-1433.

11 Goossens GH. The role of adipose tissue dysfunction in the pathogenesis of obesity-related insulin resistance. Physiol Behav 2008; 94: 206-218.

12 Christodoulides C, Laudes M, Cawthorn WP, Schinner S, Soos M, O'Rahilly S et al. The Wnt antagonist Dickkopf- 1 and its receptors are coordinately regulated during early human adipogenesis. J Cell Sci 2006; 119(Pt 12): 2613-2620.

13 Garces C, Ruiz-Hidalgo MJ, Font de Mora J, Park C, Miele L, Goldstein J et al. Notch1 controls the expression of fatty acid-activated transcription factors and is required for adipogenesis. J Biol Chem 1997; 272: 29729-29734.

14 Picard F, Kurtev M, Chung N, Topark-Ngarm A, Senawong T, Machado De Oliveira R et al. Sirt1 promotes fat mobilization in white adipocytes by repressing PPARgamma. Nature 2004; 429: 771-776.

15 Fischer-Posovszky P, Kukulus V, Tews D, Unterkircher T, Debatin KM, Fulda S et al. Resveratrol regulates human adipocyte number and function in a Sirt1-dependent manner. Am J Clin Nutr 2010; 92: 5-15.

16 He Q, Gao Z, Yin J, Zhang J, Yun Z, Ye J. Regulation of HIF-1\{alpha\} activity in adipose tissue by obesity-associated factors: adipogenesis, insulin, and hypoxia. Am J Physiol Endocrinol Metab 2011; 300: E877-E885.

17 Brakenhielm E, Cao R, Cao Y. Suppression of angiogenesis, tumor growth, and wound healing by resveratrol, a natural compound in red wine and grapes. FASEB J 2001; 15: 1798-1800.

18 Singh R, Cuervo AM. Lipophagy: connecting autophagy and lipid metabolism. Int J Cell Biol 2012; 2012: 282041.

19 Singh R, Xiang Y, Wang Y, Baikati K, Cuervo AM, Luu YK et al. Autophagy regulates adipose mass and differentiation in mice. J Clin Invest 2009; 119: 3329-3339.

20 Siklova-Vitkova M, Klimcakova E, Polak J, Kovacova Z, Tencerova M, Rossmeislova L et al. Adipose tissue secretion and expression of adipocyte-produced and stromavascular fraction-produced adipokines vary during multiple phases of weight-reducing dietary intervention in obese women. J Clin Endocrinol Metab 2012; 97: E1176-E1181.

Supplementary Information accompanies this paper on International Journal of Obesity website (http://www.nature.com/ijo) 